\title{
Effectiveness Assessment of Non- Specialized Vessel Acquisition and Operation Projects, Considering Their Suitability for Oversized Cargo Transportation
}

\author{
Oleksiy Melnyk, Mykola Malaksiano
}

At present, shipowners have to take active measures to improve the efficiency of their fleet to remain competitive on the freight market. In this respect, the development of a shipping company's fleet is immensely important due to the ability of such vessels to operate with maximum efficiency and flexibility when the structure of cargo flow is heterogeneous. At the same time, fuel expenses account for a considerable part of shipping company expenses. Fuel consumption greatly depends on ship speed. Therefore, the efficiency of maritime shipping can be greatly increased by choosing optimal speed. The purpose of this research is to develop a methodology for justifying the selection of shipping company fleet expansion projects based on cargo flow structure characteristics, considering the possibility of slow

\section{KEY WORDS}

$\sim$ Oversized cargoes

$\sim$ Tramp transportation

$\sim$ Vessel acquisition project

$\sim$ Optimal ship speed

$\sim$ Profitability index

$\sim$ Net present value

Odessa National Maritime University, Ukraine

e-mail: briz1301@ukr.net

doi: 10.7225/toms.v09.n01.002

This work is licensed under (cc) BY steaming ship operation. Net Present Value and Profitability Index were taken into account to compare the efficiency of acquisition and operation projects pertaining to ships with significantly different deadweight and market values.

\section{INTRODUCTION}

Relying on expanding bulk transportation capabilities and technological innovations, the design and operation of dry bulk ships have significantly developed since the invention of the first specialized dry bulk cargo vessel in the early 1950s. Technical changes in the speed, deadweight, lightweight and engines of main dry cargo vessel types have been tested and the trends identified have proven to be the consequences of technical improvements and economic factors alike. Owing to the growing competition in the freight market, shipowners are forced to take active measures to increase the efficiency of their fleets. In this respect, there is a need for a more profound analysis of freight flow structure trends and a more specific choice of fleet development strategies. The timely expansion of the fleet with vessels capable of operating as efficiently and as flexibly as possible under conditions of tough competition and uneven freight flow structure is immensely important. Currently, Ukraine exports significant volumes of bulk cargo to South-East Asia, and these volumes have a tendency to increase in the future. At the same time, South-East Asia is one of the world's main exporters of project cargoes. Therefore, the acquisition of vessels capable of effectively transporting bulk cargo from the Mediterranean and Black Sea countries to South-East Asian ports and heavy lift and 
oversized (HL/OS) cargo in the opposite direction is a promising course of shipping company fleet development. Methods for choosing the most effective vessels for such circumstances should therefore be devised. The intentional reduction of vessel speed to decrease fuel consumption is a common way to cut expenses in the modern shipping market. Moreover, as shipping lines are struggling to remain profitable in the currently weak freight market, slow steaming proved to be a good way to reduce operative costs and increase net profit.

\section{LITERATURE OVERVIEW}

The basic principles of modern oversized project cargo transportation, stowage and securing technologies are proposed in (IMO, 2014). In (Petraška et al. 2017), the issues of criteria selection and evaluation of the routes of carriage of HL/OS cargo are considered. The tendency of change in the shipping market and ways to improve fleet operation efficiency on the changing freight market are studied in (Moutzouris et al., 2019; Liu et al., 2018; Kou et al., 2018). The relation between the ship's cost, net earnings and profit of ownership in the dry bulk shipping industry was examined in (Moutzouris et al., 2019). Paper (Liu et al., 2018) examines the effects of crisis on the bulk shipping market and assesses the volatility characteristics of specific vessel types. The game theory model developed in (Kou et al., 2018) to study the excess shipping capacities as form of strategic behavior of ocean carriers in response to overcapacity in the competitive market. This research explains the consistently low freight rate in shipping, and proposes potential strategies for shipping industry stakeholders that would contribute to the maintenance of a sound global logistics system in maritime transportation. In paper (Chen et al., 2010), the analysis of the profit potential of dry cargo ships depending on their technical characteristics is presented.

The development of a logit voyage chartering transaction conclusion management model, the substantiation of the choice of optimal means of cargo delivery and different commercial deal registration models were provided in papers (Petraška et al., 2017; Lapkina et al., 2016a; Onyshchenko et al., 2016). Paper (Petraška et al., 2017) proposed an algorithm for the assessment of HL/OS cargo transportation, that facilitates the selection of the most appropriate route of transportation in terms of cost and time. The algorithm enables the evaluation of $\mathrm{HL} / \mathrm{OS}$ cargo transportation processes through the comparison of different modes of transportation, route segments, cargo transportation and cargo handling technology. Paper (Lapkina et al., 2016a) proposes a simulation model that allows cargo delivery scheme optimization in uncertain conditions.

The issue of optimum terms of purchase and sale of vessels and other equipment was considered in (Alizadeh et al., 2007; Lapkina et al., 2018a; Malaksiano, 2012; Kyriakou et al., 2018;
Engelen et al., 2007; Lapkina et al., 2016b), taking into account the factor of uncertainty. The realization of trading strategies combining technical rules of trade with fundamental market analysis of dry bulk cargo sales was examined in (Alizadeh et al., 2007). The issue of optimal time to enter the shipping industry was studied in (Malaksiano, 2012; Bulut et al., 2013; Merikas et al., 2008). In (Lapkina et al., 2018b) issues of purchase and sale of oceangoing vessels and port handling equipment were studied taking into account both physical and moral deterioration.

One of the key shipping efficiency improvement methods is lowering fuel consumption by reducing ship speed. Papers (Wang et al., 2013; Wong et al., 2015; Doskocz, 2012; Wang ent al., 2012; Lapkina et al., 2019; Lee et al., 2015) examine the dependence of ship operation efficiency indicators on speed. In (Wang et al., 2013), the issues of applicability, optimality and efficiency of existent and newly proposed methods of reducing fuel consumption while simultaneously maintaining a certain level of operation were analyzed, taking into account the high cost of bunkers and emissions associated with their transportation. Paper (Wong et al., 2015) analyses slow steaming sustainability initiatives and the transition from the traditional discrete costbased decision support model to new continuous utility models. The profitability of speed reduction and fuel consumption of seagoing bulk carriers was examined in (Doskocz, 2012). The study of optimal speed of container ships in each section of the route of each vessel in the liner shipping network, taking into account transshipment routes, was provided in (Wang et al., 2012). Papers (Lapkina et al., 2019; Lee et al., 2015) examined the correlation between bunkering costs, average time of cargo delivery and the profitability of ship operation.

The overview of publications indicates that research aimed at devising a methodology that would improve shipping performance by taking into account the characteristics of cargo flow structure and other features of ship operation is of great practical interest.

\section{PROBLEM FORMULATION}

The purpose of this paper is to develop a methodology that would justify the selection of shipping company fleet expansion projects based on the characteristics of the cargo flow structure, considering the possibility of slow steaming ships operation.

\section{MATERIALS AND METHODS}

The analysis of efficiency of long-term capital investments pertaining to the acquisition of ships is quite complicated. It involves extended time periods and requires comprehensive assessment of future conditions.

As Net Present Value (NPV) is an indicator used to determine the current value of all future cash flows generated by a project, 
including the initial capital investment, it is used to assess investment project efficiency. For NPV of vessel acquisition and operation projects to be calculated, all cash flows connected with such projects must be estimated. The NPV of an acquisition and operation project is determined by the following formula

$N P V=\sum_{i=1}^{T} \frac{F-R^{\text {var }}-R^{\text {perm }}-R_{i}^{\text {loan }}}{(1+p / 100)^{i}}+\frac{I_{\text {sale }}}{(1+p / 100)^{i}}-I_{0}^{\text {own }}$

where $T$ - vessel operation period, years;

$F$ - average income earned by the vessel per year, USD;

$R^{v a r}$ - average annual variable operation costs of the vessel, USD;

$R^{\text {perm }}$ - average annual permanent operation costs of the vessel, USD;

$R_{i}^{\text {loan }}$ - loan expenses for the $i$-th year, USD.

$p$-discount rate, \%;

$I_{0}^{\text {own }}$ - equity investment, USD; USD;

$I_{\text {sale }}$ - estimated cost of the vessel after operation period,

To compare the efficiency of acquisition and operation projects of vessels having significantly different deadweight, market value and NPV, the Profitability Index (PI) (Hayes et al., 2011) must also be taken into account. This index is the ratio of all discounted cash flows and the initial vessel acquisition costs:

$P I=\frac{\frac{l_{\text {sale }}}{(1+p / 100)^{T}}+\sum_{i=1}^{T} \frac{F-R^{\text {var }}-R^{\text {perm }}-R_{i}^{\text {loan }}}{(1+p / 100)^{i}}}{I_{0}^{\text {own }}}$

Permanent operation costs include crew salaries, costs associated with vessel maintenance, as well as insurance premiums.

The average annual income of a ship is calculated using the following formula

$F=\frac{\sum_{k=1}^{K} F_{k}}{\sum_{k=1}^{K} t_{p k}} \cdot T_{o p}$

where $F_{k}$ - quantity of freight received by the vessel for a round trip on the $k$-th route, USD;

$t_{p k}$ - duration of the circular voyage on the $k$-th route, days;

$T_{\text {op }}$ - operation running period in a year, days.

Average annual variable operation costs are equal to
$R^{v a r}=\frac{\sum_{k=1}^{K} F_{k}\left(R_{k}^{\text {fuel }}+F_{k} \cdot r_{b r} / 100+R_{\text {dues } k}^{\text {total }}\right)}{\sum_{k=1}^{K} t_{p k}} \cdot T_{o p}$

where $R_{k}^{\text {fuel }}$ - total bunker costs per voyage on the $k$-th route, USD;

$F_{k}$ - amount of freight per voyage on the $k$-th route, USD;

$r_{b r}$ - brokerage commission, \%;

$R_{\text {dues } k}^{\text {total }}$ - total port dues for voyage on the $k$-th route, USD;

Total bunker costs per voyage on the $k$-th route are calculated using the following formula

$$
\begin{aligned}
R_{k}^{\text {fuel }}= & r_{\text {lub }} \cdot C^{\text {ifo }} \cdot\left(q_{\text {sail }}^{\text {ifo }} \cdot t_{k}^{\text {sail }}+q_{\text {serv }}^{\text {ifo }} \cdot t_{k}^{\text {serv }}\right)+ \\
& +r_{\text {lub }} \cdot C^{\text {mdo }} \cdot\left(q_{\text {sail }}^{\text {mdo }} \cdot t_{k}^{\text {sail }}+q_{\text {serv }}^{\text {mdo }} \cdot t_{k}^{\text {serv }}\right)
\end{aligned}
$$

where $r_{\text {lub }}$ - lubricant consumption factor; day;

$q_{\text {sail }}^{\text {ifo }}-$ fuel oil (IFO) consumption during running period, $t$ /

$q_{\text {serv }}^{\text {ifo }}-$ fuel oil (IFO) consumption during port period, t/day;

Cifo - cost of (IFO 380), USD/t;

$q_{\text {sail }}^{\text {mdo }}$ - diesel oil (MDO) consumption during running period, t/day;

$q_{\text {serv }}^{\text {mdo }}$ - diesel oil (MDO) consumption during port period, $\mathrm{t} /$ day;

$\mathrm{C}^{\text {mdo }}$ - cost of diesel oil (MDO), USD/t;

$t_{k}^{\text {sail }}$ - running period of a round trip on the $k$-th route, days;

$t_{k}^{\text {serv }}$ - port period of a round trip on the $k$-th route, days;

Freight value per round trip on the $k$-th route is equal to:

$F_{k}=Q_{k}^{g r} \cdot f_{k}^{g r}+F_{k}^{p r}$

where $Q_{k}{ }^{g r}$ - estimated quantity of bulk cargo shipped per voyage in the forward direction, $\mathrm{t}$;

$f_{k}^{g r}$ - freight rate for bulk cargo in the forward direction, $\mathrm{USD} / \mathrm{t}$;

$F_{k}^{p r}$ - lump sum freight rate for the carriage of oversized project cargo in the reverse direction, USD.

The cost of loan fund usage in the $i$-th year is determined by the following formula:

$R_{i}^{\text {loan }}=l_{\text {res } i}^{\text {loan }} \cdot \frac{p}{100}+\frac{l_{\text {init }}^{\text {loan }}}{T}$

where $I_{\text {res } i}^{\text {loan }}$ - balance of loan funds at the beginning of the $i$-th year, USD;

$I_{\text {init }}^{\text {loan }}-$ total loan funds at the inception of the investment project, USD. 


\section{CALCULATED SHIP OPERATION EFFICIENCY INDICATORS, CONSIDERING THE VESSELS' POTENTIAL USE IN THE TRANSPORTATION OF OVERSIZED PROJECT CARGO}

The calculation below includes several shipping company fleet expansion options involving the acquisition of various ship types, as well as an assessment of the efficiency of those ships providing that they transport bulk cargo in one direction, and oversized project cargo in the reverse direction. The main characteristics of five proposed vessels are presented in Table 1 (Vessel Database, 2020).

Table 1.

Main characteristics of proposed vessels.

\begin{tabular}{|c|c|c|c|c|c|}
\hline & Vessel 1 & Vessel 2 & Vessel 3 & Vessel 4 & Vessel 5 \\
\hline Vessel type & general cargo ship & dry cargo ship & bulk carrier & bulk carrier & $\begin{array}{l}\mathrm{mpp} / \text { heavy lift } \\
\text { carrier }\end{array}$ \\
\hline Year of construction & 2006 & 2009 & 2003 & 2007 & 2011 \\
\hline Deadweight, $t$ & 6500 & 16800 & 28611 & 35000 & 32134 \\
\hline Draft, $m$ & 6.20 & 8.25 & 9.77 & 9.70 & 11.20 \\
\hline DWCC (D), t & 6200 & 16000 & 27800 & 34151 & 31200 \\
\hline Cubic capacity (W), m3 & 8285 & 21648 & 35762 & 44183 & 39509 \\
\hline Net tonnage (NT), m3 & 2303 & 5507 & 10098 & 11251 & 10570 \\
\hline Gross tonnage (GT), m3 & 4655 & 11927 & 16980 & 22115 & 24025 \\
\hline LOA, m & 118.60 & 148.00 & 169.26 & 193.84 & 193.90 \\
\hline Breadth, $m$ & 16.20 & 23.00 & 27.20 & 27.60 & 28.20 \\
\hline Depth, m & 7.80 & 11.80 & 13.60 & 15.80 & 15.60 \\
\hline $\begin{array}{l}\text { Hold structural non- } \\
\text { uniformity coefficient }\end{array}$ & 1.00 & 0.90 & 0.70 & 0.65 & 0.80 \\
\hline $\begin{array}{l}\text { Hatch quantity and } \\
\text { dimensions, } m\end{array}$ & $\begin{array}{l}3 \\
25.2 \times 12.6\end{array}$ & $\begin{array}{l}4 \\
16.4 \times 17.0\end{array}$ & $\begin{array}{l}5 \\
13.5 \times 16.0 \\
19.18 \times 17.6\end{array}$ & $\begin{array}{l}5 \\
18.8 \times 18.2 \\
21.0 \times 18.0\end{array}$ & $\begin{array}{l}8 / 12.64 \times 15.4 \\
25.28 \times 12.8(2) \\
37.9 \times 12.8(2) \\
31.6 \times 12.8(2) \\
12.6 \times 24.1\end{array}$ \\
\hline $\begin{array}{l}\text { Hatchway opening } \\
\text { coefficient }\end{array}$ & 0.94 & 0.73 & 0.68 & 0.64 & 1.00 \\
\hline $\begin{array}{l}\text { Number of decks and } \\
\text { their square surface, m2 }\end{array}$ & $\begin{array}{l}\text { 2/Shold-1005; } \\
\text { Sm/d-952.5 }\end{array}$ & $\begin{array}{l}\text { 2/Shold-1872; } \\
\text { Sm/d- } 1368\end{array}$ & $\begin{array}{l}2 \text { / Shold-2300; } \\
\text { Sm/d-1564 }\end{array}$ & $\begin{array}{l}\text { 2/Shold-2100; } \\
\text { Sm/d- } 1350\end{array}$ & $\begin{array}{l}\text { 3/ Shold-2315; } \\
\text { Sm/d - 3649. FL- } \\
832 . \\
\text { Sm/d-2988 }\end{array}$ \\
\hline $\begin{array}{l}\text { Permissible loads on } \\
\text { tanktop/hatches, } t\end{array}$ & TT-12 / H-1.8 & TT-16 / H-2.8 & TT-17 / H-2.0 & $\begin{array}{l}\text { TT-18 /M/DECK- } \\
2.6\end{array}$ & $\begin{array}{l}\text { TT-22, } \\
\text { TD-4.0 / M/DECK } \\
-3.0\end{array}$ \\
\hline $\begin{array}{l}\text { Quantity and SWL of ship } \\
\text { cargo gears, } t\end{array}$ & NIL & $2 \times 40$ & $4 \times 30.5$ & $4 \times 25$ & $\begin{array}{l}\text { Crane } 1 \text { - } 50 \text { mts; } \\
\text { Cranes } 2 \& 3350 \\
\text { (each) comb-700, } \\
\text { Crane 4 -100 }\end{array}$ \\
\hline $\begin{array}{l}\text { Structural features of } \\
\text { open decks and adjacent } \\
\text { areas }\end{array}$ & free open deck & $\begin{array}{l}\text { cranes positioned } \\
\text { portside }\end{array}$ & $\begin{array}{l}\text { cranes positioned } \\
\text { amidships on deck } \\
\text { masthouses }\end{array}$ & $\begin{array}{l}\text { cranes positioned } \\
\text { amidships on deck } \\
\text { masthouses }\end{array}$ & $\begin{array}{l}\text { cranes positioned } \\
\text { amidships }\end{array}$ \\
\hline
\end{tabular}


used for the transportation of B2 and B3 cargoes. Some of their limitations are the weight of cargo units and the local strength of tank top deck or hatch covers. The majority of type 3 and type 4 vessels have cargo-handling facilities. Their shortcoming is the inaccessibility of musthouses, deck standers and superstructures, which, being located in the cross deck areas and on the main deck, may obstruct the handling of oversized cargoes over $18 \mathrm{~m}$ in length. Optimized cargo stowage arrangement on the decks of Vessel 3 and Vessel 4 could be similar to that of Vessel 1 and Vessel 2 (Figure 1), provided that the length of free space between the deck structures is not exceeded.

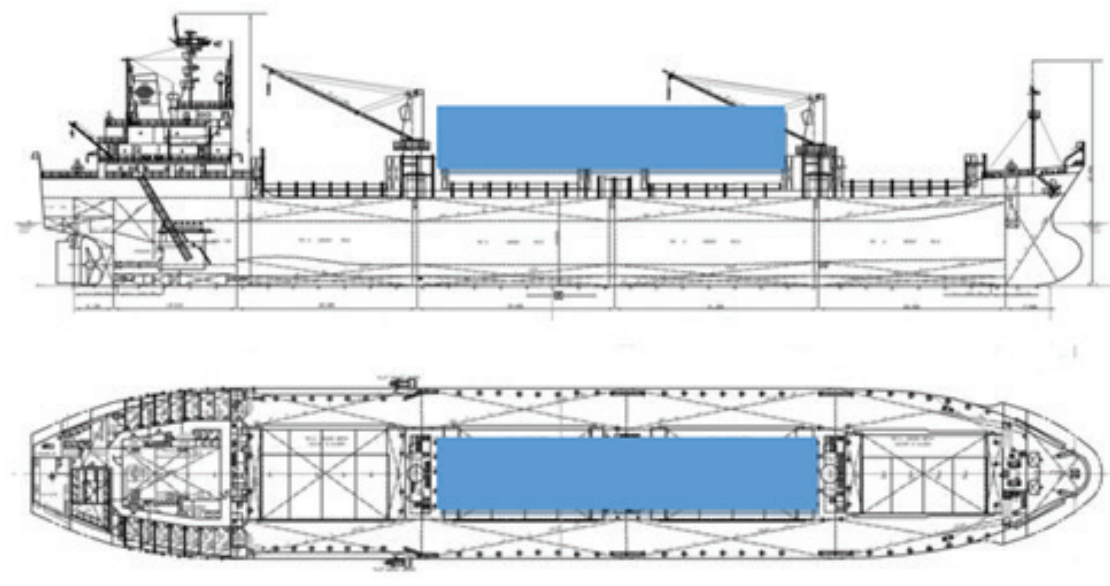

Figure 1.

Loading of B2 type cargo on the deck of Vessel 2.

As for B2 cargo, it should be noted that stowage is complicated by the location of cranes in the centerline of the vessel and the presence of deck mashouses between the holds. Therefore, hatch cover dimensions will be a limiting factor with respect to the length of intended cargo units. However, this problem can be solved by constructing separating platforms that allow cargo units to be lifted above the level of deck structures located on the cross decks and placed on hatch covers adjacent to them.

The overall breadth of such cargo unit, however, may not exceed the distance between the crane and the ship's side (Figure 2).

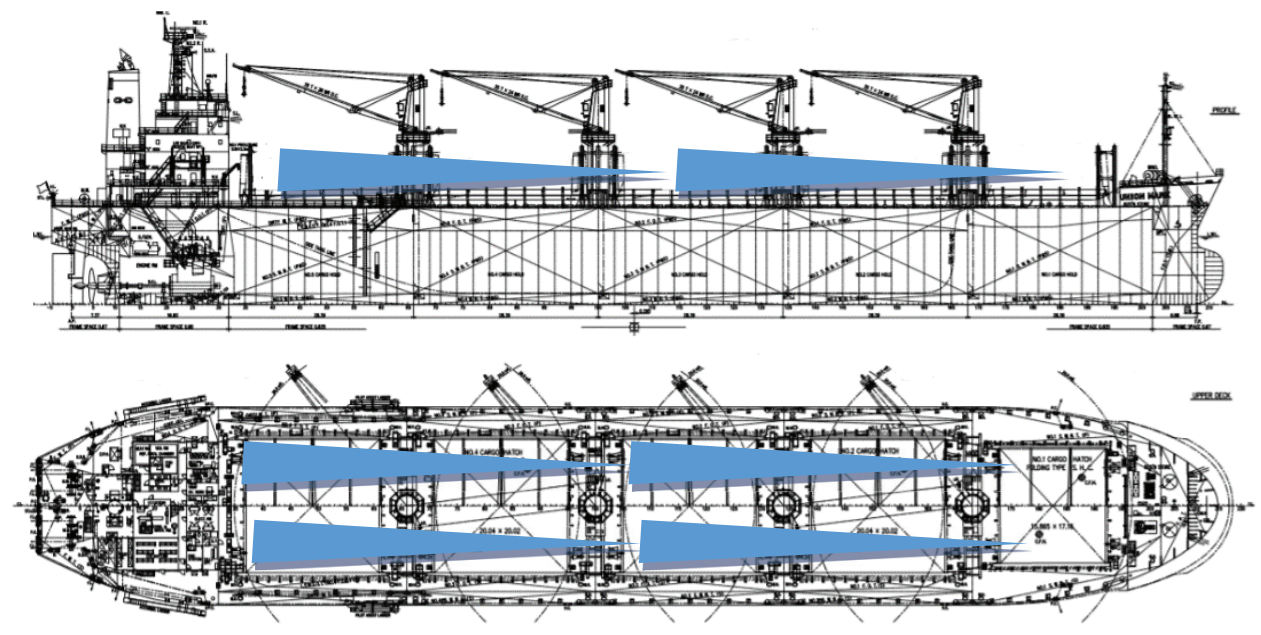

Figure 2.

Stowage of B1 type cargo on the deck of Vessel 4. 
The majority of type 4 vessels are not equipped with square shaped holds, but rather have upper and lower hoppers used to trim bulk cargo. The upper inclined bulkheads form the upper topside tanks used for ballast waters. Lower hoppers forming slopes also function as double bottom ballast/fuel tanks. Such sloping bulkheads situated in the lower and upper parts limit the hold's full cubic capacity and leave only hatchway area available for break-bulk cargo stowage.

Construction elements of cargo holds that aggravate the stowage of cargoes such as break-bulk and equipment, containers and oversized units, as well as cargo requiring additional securing measures and methods, increase loading time and costs.

Vessel 4 type ships and similar bulk carriers having the deadweight of over $30000 \mathrm{t}$ are usually not efficient for the carriage of oversized cargo since hatch dimensions do not facilitate the transportation of the majority of oversized cargoes in the holds, and even with the optimal stowage of deck cargo, the vessel remains significantly short shipped.

Multipurpose carrier, Vessel 5, is a specialized vessel for the transportation of a wide variety of commodities, including containerized, oversized and heavy lift cargoes. Vessel 5 has a number of important advantages over other proposed vessels, including cranes with sufficient single and combined lifting capacity, two heavy lift cranes each having the capacity of up to $350 \mathrm{t}$, providing tandem-lifting capacity up to $700 \mathrm{t}$. The specific construction of deck cargo areas allows the vessel to carry all groups of cargo according to the disposition requirements.

Table 3.

Average loading and unloading times (hours) of different types of oversized project cargo for proposed vessels, including preloading survey and cargo securing times.

Oversized project cargo types

\begin{tabular}{llll}
\hline & B1 & B2 & B3 \\
\hline Vessel 1 & $24 / 48$ & $24 / 48$ & $24 / 72$ \\
\hline Vessel 2 & $72 / 120$ & $96 / 144$ & $120 / 192$ \\
\hline Vessel 3 & $120 / 168$ & $120 / 192$ & $168 / 240$ \\
\hline Vessel 4 & $168 / 336$ & $168 / 336$ & $240 / 360$ \\
\hline Vessel 5 & $120 / 240$ & $120 / 240$ & $192 / 288$
\end{tabular}

Table 4.

Lump sum freight rates for proposed vessels at the specified routes.

Lump sum rate, thousand USD

\begin{tabular}{llll}
\hline $\begin{array}{l}\text { Proposed } \\
\text { vessel }\end{array}$ & $\begin{array}{l}\text { Shanghai - } \\
\text { Odesa }\end{array}$ & $\begin{array}{l}\text { Guandzhou- } \\
\text { Yuzhniy }\end{array}$ & $\begin{array}{l}\text { Qingdao- } \\
\text { Chernomosk }\end{array}$ \\
\hline Vessel 1 & 263.6 & 257.8 & 269.5 \\
\hline Vessel 2 & 438.7 & 427.7 & 449.6 \\
\hline Vessel 3 & 539.3 & 523.5 & 555.2 \\
\hline Vessel 4 & 555.3 & 539.0 & 571.6 \\
\hline Vessel 5 & 1243.5 & 1206.9 & 1280.1 \\
\hline
\end{tabular}

Table 5.

NPV and PI results for proposed vessels at sea speeds.

\begin{tabular}{lll} 
Proposed vessel & NPV, thousand USD & PI \\
\hline Vessel 1 & 733.15 & 1.92 \\
\hline Vessel 2 & 1669.97 & 2.04 \\
\hline Vessel 3 & 1819.21 & 1.96 \\
\hline Vessel 4 & 521.97 & 1.24 \\
\hline Vessel 5 & 1039.02 & 1.33 \\
\hline & &
\end{tabular}

Table 3 shows loading and unloading times of different types of cargoes for the specified proposed vessels, determined based on the ships' characteristics and cargo shipping options. Loading and unloading times have a direct impact on the duration of ship handling in port $t_{k}^{\text {serv }}$.

Calculations have shown that the highest NPV was reached in the Vessel 3 acquisition project. At the same time, Vessel 2 had the highest investment efficiency, since this Proposed vessel's acquisition project had the highest PI value (Table 5). As the results presented in Table 5 were obtained at sea speeds, before making any conclusions about the expediency of purchasing any of the considered vessels, it would be reasonable to additionally research their efficiency indicators at different speeds. 


\section{JUSTIFICATION OF THE SELECTION OF OVERSIZED PROJECT CARGO TRANSPORTATION VESSEL, TAKING INTO ACCOUNT THE POSSIBILITY OF SLOW STEAMING OPERATION}

The influence of speed on the values of proposed vessels operation efficiency indicators was established using regression dependencies of fuel oil consumption on vessel speed (Table 6). Dependencies in Table 6 were obtained from actual statistical data from ships, using standard regression analysis methods.

The dependence of ship operation efficiency indicators on speed can be calculated using formulas (1), (2), that into account the dependence of fuel oil consumption on speed (Table 6). Table 7 shows $N P V$ and $P I$ values at different speeds.
Table 6.

Dependence of fuel oil consumption on ship speed.

Proposed Function describing the dependence of fuel vessel consumption on vessel speed

\begin{tabular}{ll}
\hline Vessel 1 & $\mathrm{q}_{\text {sail }}^{\text {ifo }}(v)=0.0104 \mathrm{v}^{3}-0.1984 \mathrm{v}^{2}+1.5098 \mathrm{v}-2.73$ \\
\hline Vessel 2 & $\mathrm{q}_{\text {sail }}^{\text {ifo }}(\mathrm{v})=0.0182 \mathrm{v}^{3}-0.2519 \mathrm{v}^{2}+1.3982 \mathrm{v}-1.2984$ \\
\hline Vessel 3 & $\mathrm{q}_{\text {sail }}^{\text {ifo }}(\mathrm{v})=0.0126 \mathrm{v}^{3}-0.0984 \mathrm{v}^{2}+0.3016 \mathrm{v}+1.9468$ \\
\hline Vessel 4 & $\mathrm{q}_{\text {sail }}^{\text {ifo }}(\mathrm{v})=0.0091 \mathrm{v}^{3}-0.0343 \mathrm{v}^{2}+0.2488 \mathrm{v}+1.4179$ \\
\hline Vessel 5 & $\mathrm{q}_{\text {sail }}^{\text {ifo }}(\mathrm{v})=0.0042 \mathrm{v}^{3}+0.0877 \mathrm{v}^{2}-0.2659 \mathrm{v}+3.2776$ \\
\hline
\end{tabular}

Table 7.

Dependence of NPV and PI on the speed of proposed vessels.

\begin{tabular}{|c|c|c|c|c|c|c|c|c|c|c|}
\hline \multirow{2}{*}{$\begin{array}{l}\text { Ship } \\
\text { speed, kn }\end{array}$} & \multicolumn{2}{|l|}{ Vessel 1} & \multicolumn{2}{|l|}{ Vessel 2} & \multicolumn{2}{|l|}{ Vessel 3} & \multicolumn{2}{|l|}{ Vessel 4} & \multicolumn{2}{|l|}{ Vessel 5} \\
\hline & $\begin{array}{l}\text { NPV, } \\
\text { thousand } \\
\text { USD }\end{array}$ & PI & $\begin{array}{l}\text { NPV, } \\
\text { thousand } \\
\text { USD }\end{array}$ & PI & $\begin{array}{l}\text { NPV, } \\
\text { thousand } \\
\text { USD }\end{array}$ & $P I$ & $\begin{array}{l}\text { NPV, } \\
\text { thousand } \\
\text { USD }\end{array}$ & $P I$ & $\begin{array}{l}\text { NPV, } \\
\text { thousand } \\
\text { USD }\end{array}$ & $P I$ \\
\hline 5.0 & -1154.7 & -0.44 & -517.7 & 0.68 & -1453.7 & 0.23 & -1972.5 & 0.10 & -3600.0 & -0.14 \\
\hline 5.5 & -851.2 & -0.06 & 2.6 & 1.00 & -882.4 & 0.54 & -1415.4 & 0.36 & -2779.0 & 0.12 \\
\hline 6.0 & -564.9 & 0.29 & 482.7 & 1.30 & -356.9 & 0.81 & -912.1 & 0.59 & -2029.0 & 0.36 \\
\hline 6.5 & -297.5 & 0.63 & 917.6 & 1.57 & 121.2 & 1.06 & -462.3 & 0.79 & -1347.8 & 0.57 \\
\hline 7.0 & -50.3 & 0.94 & 1301.9 & 1.81 & 550.7 & 1.29 & -65.9 & 0.97 & -733.4 & 0.77 \\
\hline 7.5 & 174.9 & 1.22 & 1629.1 & 2.02 & 930.0 & 1.49 & 277.4 & 1.13 & -184.0 & 0.94 \\
\hline 8.0 & 376.7 & 1.47 & 1892.6 & 2.18 & 1257.7 & 1.66 & 567.6 & 1.26 & 302.4 & 1.10 \\
\hline 8.5 & 553.3 & 1.69 & 2084.7 & 2.30 & 1532.1 & 1.81 & 804.6 & 1.37 & 727.5 & 1.23 \\
\hline 9.0 & 703.2 & 1.88 & 2197.4 & 2.37 & 1751.5 & 1.92 & 988.4 & 1.45 & 1092.9 & 1.35 \\
\hline 9.5 & 824.5 & 2.03 & 2222.0 & 2.39 & 1914.4 & 2.01 & 1118.8 & 1.51 & 1400.3 & 1.44 \\
\hline 10.0 & 915.8 & 2.14 & 2149.0 & 2.34 & 2019.0 & 2.06 & 1195.8 & 1.54 & 1651.1 & 1.52 \\
\hline 10.5 & 975.2 & 2.22 & 1968.6 & 2.23 & 2063.5 & 2.09 & 1219.2 & 1.55 & 1846.8 & 1.58 \\
\hline 11.0 & 1000.9 & 2.25 & 1670.0 & 2.04 & 2046.2 & 2.08 & 1188.6 & 1.54 & 1988.6 & 1.63 \\
\hline 11.5 & 991.4 & 2.24 & - & - & 1965.4 & 2.03 & 1103.9 & 1.50 & 2078.0 & 1.66 \\
\hline 12.0 & 944.8 & 2.18 & - & - & 1819.2 & 1.96 & 964.7 & 1.44 & 2116.1 & 1.67 \\
\hline 12.5 & 859.3 & 2.07 & - & - & - & - & 770.9 & 1.35 & 2104.2 & 1.67 \\
\hline 13.0 & 733.1 & 1.92 & - & - & - & - & 522.0 & 1.24 & 2043.2 & 1.65 \\
\hline 13.5 & - & - & - & - & - & - & - & - & 1934.3 & 1.61 \\
\hline 14.0 & - & - & - & - & - & - & - & - & 1778.5 & 1.56 \\
\hline 14.5 & - & - & - & - & - & - & - & - & 1576.8 & 1.50 \\
\hline 15.0 & - & - & - & - & - & - & - & - & 1330.0 & 1.42 \\
\hline 15.5 & - & - & - & - & - & - & - & - & 1039.0 & 1.33 \\
\hline
\end{tabular}


Figure 3 and Figure 4 show graphs of NPV and PIdependence on proposed vessel speed.

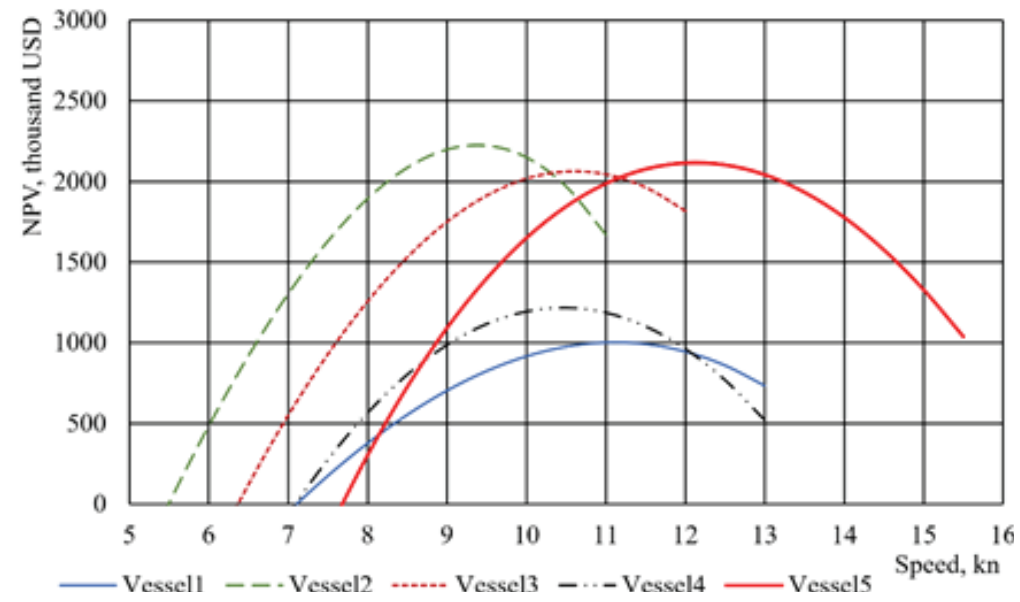

Figure 3.

Dependence of NPV on ship speed.

Figure 3 and 4 show the comparison of NPV and P/values for proposed vessel acquisition projects, at sea speeds and optimal speeds (Tables 5, 8). Figure 3 demonstrates that the highest NPV values are achieved in the acquisition projects and operation of the following vessels: Vessel 2, Vessel 5 and Vessel 3, provided that these vessels are used at optimal speeds specified in Table 8.

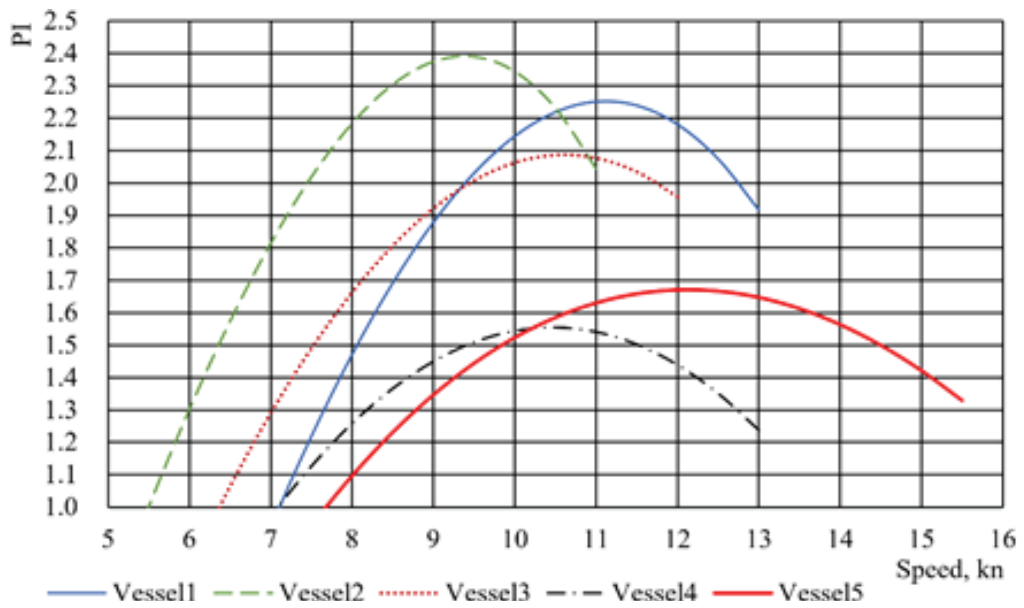

Figure 4

Dependence of PI values on the speed of proposed vessels.

Maximum NPV and PI values for proposed vessels, that can be achieved at optimal speed, are presented in Table 8 . 
Table 8.

Maximum NPV and PI values at optimal speed.

\begin{tabular}{lllll} 
Proposed vessel & Optimal speed, $\mathrm{kn}$ & \multirow{2}{*}{$\begin{array}{c}\text { Average running time } \\
\text { in one direction, days }\end{array}$} & & Maximum values at optimal speed \\
\cline { 4 - 6 } & & & NPV, thousand USD & $P I$ \\
\hline Vessel 1 & 11.1 & 31.1 & 1000.94 & 2.25 \\
\hline Vessel 2 & 9.4 & 36.4 & 2222.00 & 2.39 \\
\hline Vessel 3 & 10.6 & 32.4 & 2063.50 & 2.09 \\
\hline Vessel 4 & 10.5 & 32.7 & 1219.17 & 1.55 \\
\hline Vessel 5 & 12.1 & 28.5 & 2116.14 & 1.67 \\
\hline
\end{tabular}

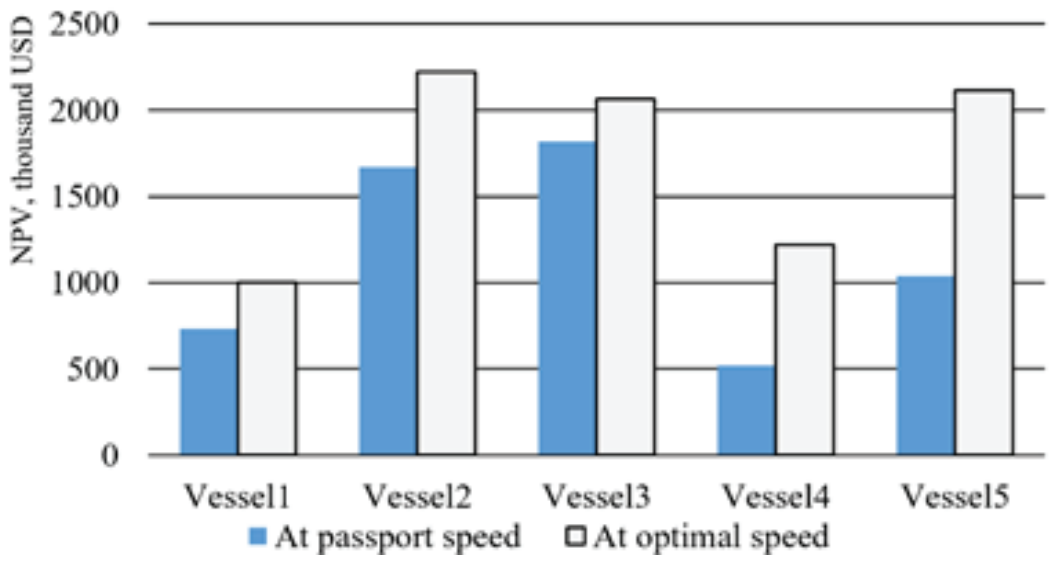

Figure 5.

Comparison of NPV values for proposed vessel acquisition projects at sea speed and optimal speed.

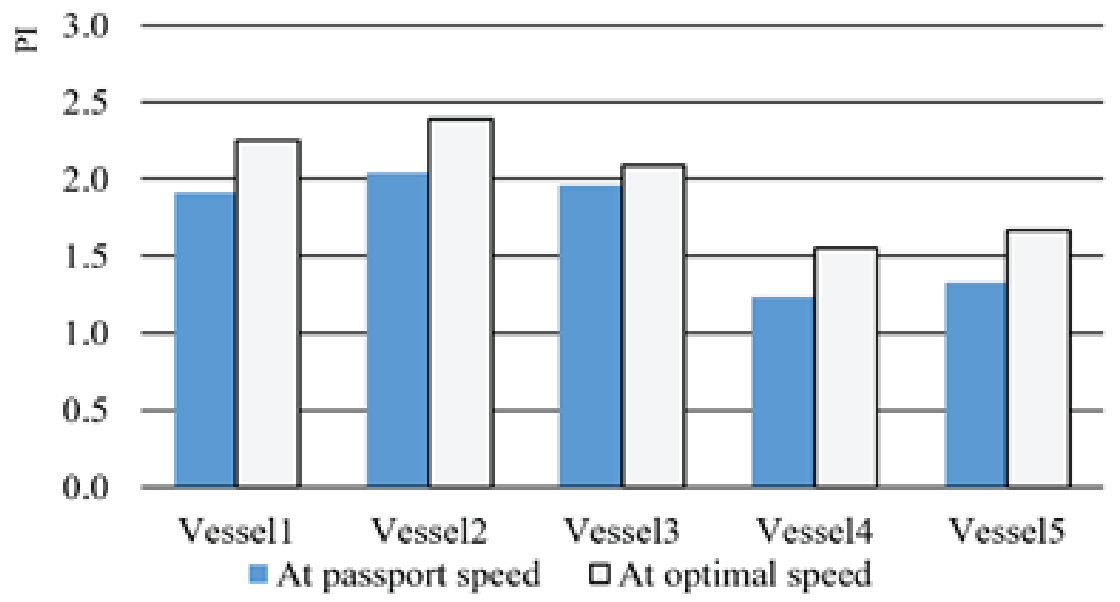

Figure 6.

Comparison of PI values for proposed vessel acquisition projects at sea speed and optimal speed. 
Vessel 1 has the lowest maximum NPV among all proposed vessels (1001 thousand USD). In terms of efficiency of acquisition and operation of the considered vessels based on the profitability index, the most preferable projects are the acquisition of Vessel 2, Vessel 1 and Vessel 3 (with PI values 2.39, 2.25 and 2.09, respectively), i.e. vessels with low tonnage (Figure 4).

\section{RESULTS AND DISCUSSION}

The comparison of charts in Figure 5 and Figure 6 shows that at optimal speed, Vessel 5 has a sufficiently high NPV, only slightly different from the maximum NPV of Vessel 2 (2,116 vs. 2,222 thousand USD). However, the PI value of Vessel 5 is noticeably inferior to the $P I$ values of all other considered vessels except Vessel 4, at any speed, since the acquisition of Vessel 5 requires a much higher capital investment than the acquisition of other proposed vessels. Therefore, in spite of the fact that Vessel 5 has the capacity to generate the highest freightage, the profitability of acquisition and operation of Vessel 5 is rather low even at optimal speed. By contrast, Vessel1 has high PI value, and her acquisition has very low NPV in comparison with other proposed vessels since the market value of Vessel 1 is much lower than the value of other vessels considered. In spite of her low freightage in comparison with other proposed vessels, the income to expenses ratio of Vessel1 is quite satisfactory at optimal speed. Thus, under the operational conditions of the considered vessels for the carriage of the specified cargoes at the stipulated routes, sailing at optimum speed, the highest NPV values were obtained for Vessel 5 and Vessel 2 acquisition projects (2,116 vs. 2,222 thousand USD). However, the project of acquisition of Vessel 5 is noticeably inferior to the project of acquisition of Vessel 2 in terms of the investment performance index PI (1.67 vs. 2.39).

When choosing the most appropriate vessel, attention should also be paid to the range of speeds at which she can be optimally used. If a vessel can be used optimally at a wide speed range, the shipping company can be more flexible in the coordination of freight rates and delivery terms in the future, due to its ability to operate efficiently at multiple speeds, which is very important in the unstable freight market conditions.

\section{CONCLUSION}

In most cases, the structure of cargo flows is heterogeneous with the number of peculiarities in each individual case. Therefore, the achievement of maximum efficiency in cargo transportation requires the characteristics of the existing cargo flow structure to be taken into account. In this respect, the development of quantitative methods for the justification of the selection of optimum vessel type for operation under the stipulated conditions is of great practical interest.
The paper proposes a methodology for the justification of the selection of a vessel for bulk and oversized cargo transportation, given the possibility of slow steaming operation. In some instances, shipping companies have limited own resources, and debt financing entails significant additional costs. This is particularly true of fleet development of Ukrainian shipping companies. Therefore, the efficiency of investments into own fleet development was assessed using the PI indicator as the main criterion for choosing a vessel acquisition and operation project.

Calculations have shown that the efficiency of maritime shipping could be significantly improved by choosing optimal ship speed. It was also shown that under conditions of heterogeneous cargo flow structure, the use of large tonnage bulk carriers and specialized vessels designed for transportation of oversized cargoes is less effective than the use of mini bulk carriers with the capacity of under $10000 \mathrm{t}$ deadweight.

\section{REFERENCES}

Alizadeh, A.H. \& Nomikos, N.K., 2007. Investment timing and trading strategies in the sale and purchase market for ships. Transportation Research Part B: Methodological, 41(1), pp.126-143. Available at:

http://dx.doi.org/10.1016/j.trb.2006.04.002.

Bulut, E., Duru, O. \& Yoshida, S., 2013. Market entry, asset returns, and irrational exuberance: asset management anomalies in dry cargo shipping. International Journal of Shipping and Transport Logistics, 5(6), p.652. Available at:

http://dx.doi.org/10.1504/ijstl.2013.056851.

Chen, S., Frouws, K. \& Van de Voorde, E., 2010. Technical changes and impacts on economic performance of dry bulk vessels. Maritime Policy \& Management, 37(3), pp.305-327. Available at:

http://dx.doi.org/10.1080/03088831003700710.

Doskocz, D., 2012. Profitability of Reduction of Speed and Fuel Consumption for Sea Going Bulk Carriers. Folia Oeconomica Stetinensia, 11(1), pp. 132-139. Available at: http://dx.doi.org/10.2478/v10031-012-0019-4.

Engelen, S., Dullaert, W. \& Vernimmen, B., 2007. Multi-Agent Adaptive Systems in Dry Bulk Shipping. Transportation Planning and Technology, 30(4), pp.377-389. Available at:

http://dx.doi.org/10.1080/03081060701461774.

Hayes, R. et al., 2011. Operations, Strategy, and Technology: Pursuing the Competitive Edge. John Wiley \& Sons.

IMO, 2014. The Code of Practice for Packing of Cargo Transport Units (CTU Code), IMO/ILO/UNECE.

Kou, Y. \& Luo, M., 2015. Strategic capacity competition and overcapacity in shipping. Maritime Policy \& Management, 43(4), pp. 389-406. Available at: http://dx.doi.org/10.1080/03088839.2015.1105395.

Kyriakou, I. et al., 2017. Income uncertainty and the decision to invest in bulk shipping. European Financial Management, 24(3), pp.387-417. Available at: http:// dx.doi.org/10.1111/eufm.12132.

Lapkina, I. \& Malaksiano, M., 2016b. Optimization of the structure of seaport equipment fleet under unbalanced load. Actual Problems of Economics, 9(183), pp. 364-371. 
Lapkina, I. \& Malaksiano, M., 2016a. Modelling and optimization of perishable cargo delivery system through Odesa port. Actual Problems of Economics, 3(177), pp. 353-365.

Lapkina, I. \& Malaksiano, M., 2018a. Estimation of fluctuations in the performance indicators of equipment that operates under conditions of unstable loading Eastern-European Journal of Enterprise Technologies, 1(3(91)), pp.22-29. Available at:

http://dx.doi.org/10.15587/1729-4061.2018.123367.

Lapkina, I. \& Malaksiano, M., 2018b. Elaboration of the equipment replacement terms taking into account wear and tear and obsolescence. Eastern-European Journal of Enterprise Technologies, 3(3(93)), pp. 30-39. Available at: http://dx.doi.org/10.15587/1729-4061.2018.133690.

Lapkina, I. et al., 2019. To the issue of the possibility of operating vessels at slow speeds Scientific notes of Taurida National V.I. Vernadsky University. Series:Technical Sciences, 4(2), pp. 134-140. Available at:

http://dx.doi.org/10.32838/2663-5941/2019.4-2/22.

Lee, C.-Y., Lee, H.L. \& Zhang, J., 2015. The impact of slow ocean steaming on delivery reliability and fuel consumption. Transportation Research Part E: Logistics and Transportation Review, 76, pp. 176-190. Available at: http://dx.doi.org/10.1016/j.tre.2015.02.004.

Liu, J. \& Chen, F., 2018. Asymmetric volatility varies in different dry bulk freight rate markets under structure breaks. Physica A: Statistical Mechanics and its Applications, 505, pp. 316-327. Available at:

http://dx.doi.org/10.1016/j.physa.2018.02.165

Malaksiano, N., 2012. On the stability of economic indicators of complex port equipment usage. Actual Problems of Economics, 12(138), pp. 226-233.

Merikas, A.G., Merika, A.A. \& Koutroubousis, G., 2008. Modelling the investment decision of the entrepreneur in the tanker sector: choosing between a second-hand vessel and a newly built one. Maritime Policy \& Management, 35(5), pp.433-447.
Available at:

http://dx.doi.org/10.1080/03088830802352053.

Moutzouris, I.C. \& Nomikos, N.K., 2019. Earnings yield and predictability in the dry bulk shipping industry. Transportation Research Part E: Logistics and Transportation Review, 125, pp. 140-159. Available at:

http://dx.doi.org/10.1016/j.tre.2019.03.009

Onyshchenko, S., Koskina, Y. \& Savelieva, I., 2016. Developing a logit model for the provision of the process of managing the conclusion of voyage chartering transactions. Eastern-European Journal of Enterprise Technologies, 6(3(84)), pp. 26-31. Available at:

http://dx.doi.org/10.15587/1729-4061.2016.85233.

Petraška, A. et al., 2017. Algorithm for the assessment of heavyweight and oversized cargo transportation routes. Journal of Business Economics and Management, 18(6), pp. 1098-1114. Available at: http://dx.doi.org/10.3846/16111699.2017.1334229.

Vessel Database, 2020. Online source. AIS Ship Positions. Available at: https://www. vesselfinder.com/vessels.

Wang, S. \& Meng, Q., 2012. Sailing speed optimization for container ships in a liner shipping network. Transportation Research Part E: Logistics and Transportation Review, 48(3), pp. 701-714. Available at: http://dx.doi.org/10.1016/j.tre.2011.12.003

Wang, S., Meng, Q. \& Liu, Z., 2013. Bunker consumption optimization methods in shipping: A critical review and extensions. Transportation Research Part E: Logistics and Transportation Review, 53, pp. 49-62. Available at: http://dx.doi.org/10.1016/j.tre.2013.02.003.

Wong, E.Y.C. et al., 2015. An utility-based decision support sustainability model in slow steaming maritime operations. Transportation Research Part E: Logistics and Transportation Review, 78, pp. 57-69. Available at: http://dx.doi.org/10.1016/j.tre.2015.01.013. 